\title{
国立久里浜養護学校の教室ユニットの使われ方に関する研究 A STUDY OF CLASSROOM UNITS AT THE NATIONAL KURIHAMA SCHOOL FOR HANDICAPPED CHILDREN
}

\author{
関 澤勝一* \\ Katsuichi SEKIZAWA
}

\begin{abstract}
The purpose of this study is to investigate the use of classrooms in the National Kurihama School for Hnadicapped Children. The school provides educational treatment for severely handicapped children, in cooperation with the National Institute of Special Education. A distinctive feature of the school is the structure of classroom unit: the school contains six classroom units, each of which is for four to five pupils and consists of three teaching spaces, a study room for teachers, a children's toilet, and a storage room. the total area of the unit is $140 \mathrm{~m}^{2}$. This study revealed that the structure and total area of each classroom unit were appropriate for educating four to five handicapped children.
\end{abstract}

\author{
Keywords:classroom unit, severely and/or multiply handicapped children, \\ semi open space \\ 教室ユニット、重度・重複障害児、セミオープンスペース
}

\section{はしがき}

本稿は著者が基本計画(1970年)を担当した国立久里浜養護 学校(以下、本校と略す)の学習スペースの一部である教室ユ ニット注1) の使われ方を調查研究したものである。調查の内 容は、各教室ユニット内における幼児と児童の動線の記録と、 各教室ユニットの担任教諭について行った使われ方に関する ヒヤリング調查である。本校は 1973 年に開校し、この調查を 実施した 1994 年現在、 22 年間を経過している。この間、教育 対象とする幼児・児童の人数及び障害の種類と程度は大きく は変化していない。学校の設置目的は隣接する国立特殊教育 総合研究所注2)(以下、研究所と略す) と相互協力のもとに重 度・重複の障害をもつ幼児・児童を対象とする教育を行うこ とにあった。本校は「学校教育の対象に下限のないことを実 践的に示し小、注3)1979年の養護学校の義務制実施 ${ }^{\text {注4) }}$ に対して 先行的な役割を果たした。本調查研究は設立時における筆者 が提案した計画条件と現在、実践されている学習形態を比較 検討し、今後の重度・重複児の学習・生活空間を計画する場合 の基礎資料を得ることにある。

\section{1 国立久里浜養詿学校の概要(1973 年〜 1994 年)}

\section{1-1-1部の構成と幼児・児童の在籍の推移}

本校は幼稚部( $3 \sim 5$ 歳児、定員 18 人)及び小学部( $1 \sim 6$ 年生、定員 36 人)の 2 部から構成されている。

表一 1 は 1994 年度 (1995 年 3 月 31 日現在)の部別、障害区 分別にみた幼児・児童一覧である。合計 26 人、定員合計は 54 人であるか、過去 22 年間この定員に達した年度はない。本校 の入学日は原則として 4 月 1 日であるが各学期( 3 学期制)の 間に転入、転出することができる。重度・重複障害を有する 幼児・児童を 6 つの障害区分に分けている。この区分は本校 が研究所設立段階(1970年 3 月)において研究所の「附属実験 教育施設」として計画されたため研究所の研究部区分と関連 している。したがって、この障害区分は創設以来変更されて いない。障害の区分別にみると精神薄弱を伴う肢体不自由(表 の中では肢体不自由と記載されている)が 12 人(全員の 46.2 \%)ともっとも多い。次いで重度精神薄弱(表の中では精神薄 弱と記載されている) 6 人、情緒障害 4 人、望・精神薄弱 2 人、 盲・精神薄弱、盲・䆍・精神薄弱がそれぞれ 1 人ずつ在籍して いる。

図ー 1 は在籍幼児・児童数を設立年度から 1994 年まで 22 年 間の推移を示したものである。(いずれも当年度 3 月31日現在)

\footnotetext{
* 日本大学理工学部建築学科 教授・博士 (工学)
} 

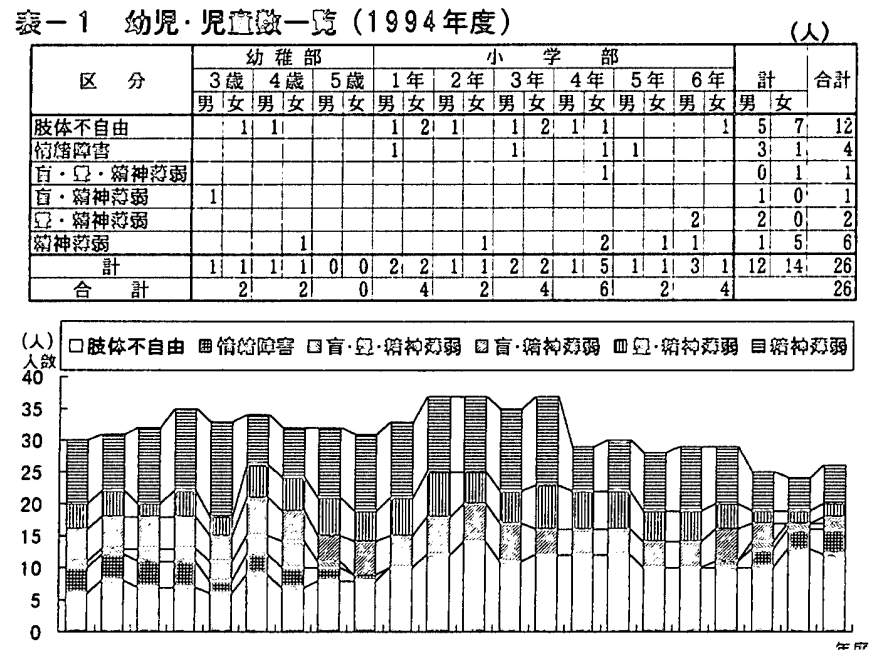

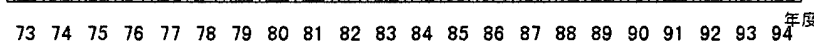

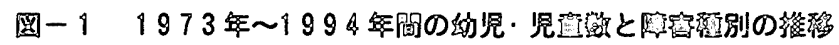

延在籍幼児。児童数の合計は 689 人、年度別にみると最大人 数は 1983 年、 84 年、 86 年の 37 人である。最小人数は、1993 年の 24 人、 22 年間の平均は 31.3 人である。1990 年代の減少 は全国的な幼児・児童数の減少傾向に加えて、学校所在地の 神奈川県を除いた他県からの在籍幼児。児童が減少したこと と関連している。

神奈川県に居住する在籍数の比率は、開校時の $53 \%$ (この年 度は開校に伴い学校が直接全国的に志願者を募集した。開校 翌年からは研究所で教育相談を受けた幼児・児童の中から入 学者を選考している)を最低として、最高は 1980 年の $84 \%$ を 経て $1988 \sim 1991$ 年間は $60 \%$ 台に減少し、1994 年では神奈川 県出身者は全体の $76 \%$ である。

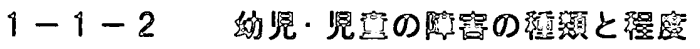

障害区分別にみると重度䄇神薄弱は 22 年間の合計が 221 人 と最も多く、続いて肢体不自由(重度精神薄弱を伴う) 214 人、 暂・崝神薄弱 100 人、盲・精神薄弱 96 人、情緒障害 38 人、盲。 暂・精神藻弱が 20 人である。図ー 2 は本校が実施した(1994 年 7 月)「遠城寺式乳幼児分析的発達検典表」 ${ }^{\text {注 } 5)}$ による検查 デー夕(久里浜著藵学校教育第 22 年報による)を作図したもの である。移動運動は発達年齢 $1: 0$ 年(寝た位置から起きて座る ことができる)赤満が 16 人いる。基本的習慣についても発達 年龄 $1: 0$ 年(父母兄弟がわかる)圭満が 15 人、言語理解の発達 年齡 $1: 0$ 年(一語出る)圭満が 15 人であり障害が重度であるこ とを示している。

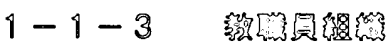

定員、現員ともに 56 人、他に非常勤の学校医 8 人、学校崡 科医 1 人、学校薬片師 1 人の合計 66 人である。この内、校長、 教頭、養護教諭を除いた教諭の人数は定員、現員ともに $29 人$ である。教室指導からみると第 1 教室〜第 6 教室まで、全て 4 人の教諭 $(4$ 人 $\times 6$ 教室 $=24$ 人) が担任しており、別に訪問 教育として 2 人が担任している。実際の指導には研究所が行 なっている研修制度 ${ }^{\text {活 })}$ によって研修を受けている研修生の中 から 2 人を限度として加わることがあり、さらに研究所の研 究員が 1 人加わる。したがって 1 つの教室(幼児。児童数平均 4 人)に対して教諭など指導にあたる人数は最大 7 人となる。

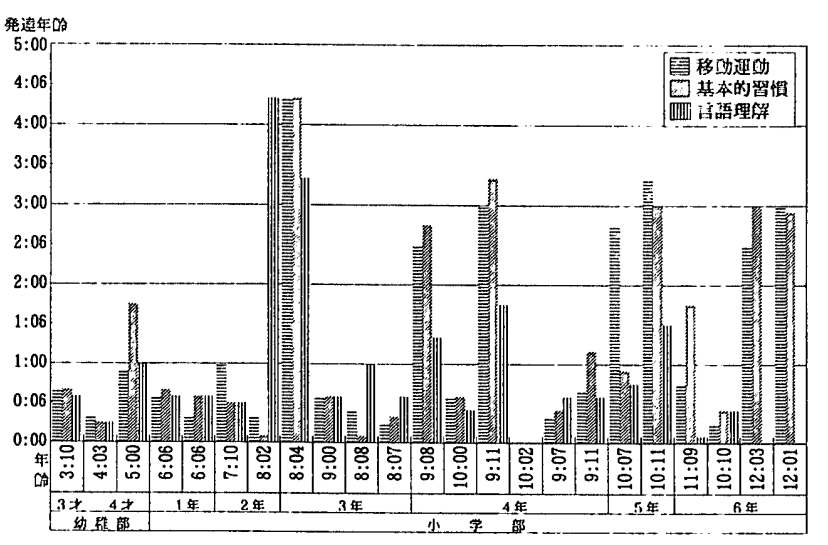

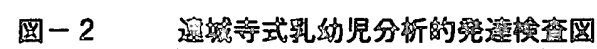
（检空対鱼児23名;1994年实施）

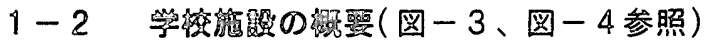

本校は研究所(研修施設を含む)との相互協力のもとに運営 されている。学校としての校地面積は、11,864 $\mathrm{m}^{2}$ 、校舎は前 述したように、開校当時は研究所附属実験施設として設計さ れたため、単独に養護学校として運営するために必要な諸室、 例えば特別教室、屋内体育館など必要な床面積を欠いていた。 このため翌年 1974年にはプレイルーム、1979年には南庭屋外 遊戯施設を整備し、1984 年に研究管理棟を增築した。1996 年 度現在、校舎延面積は $2,649 \mathrm{~m}^{2}$ 。
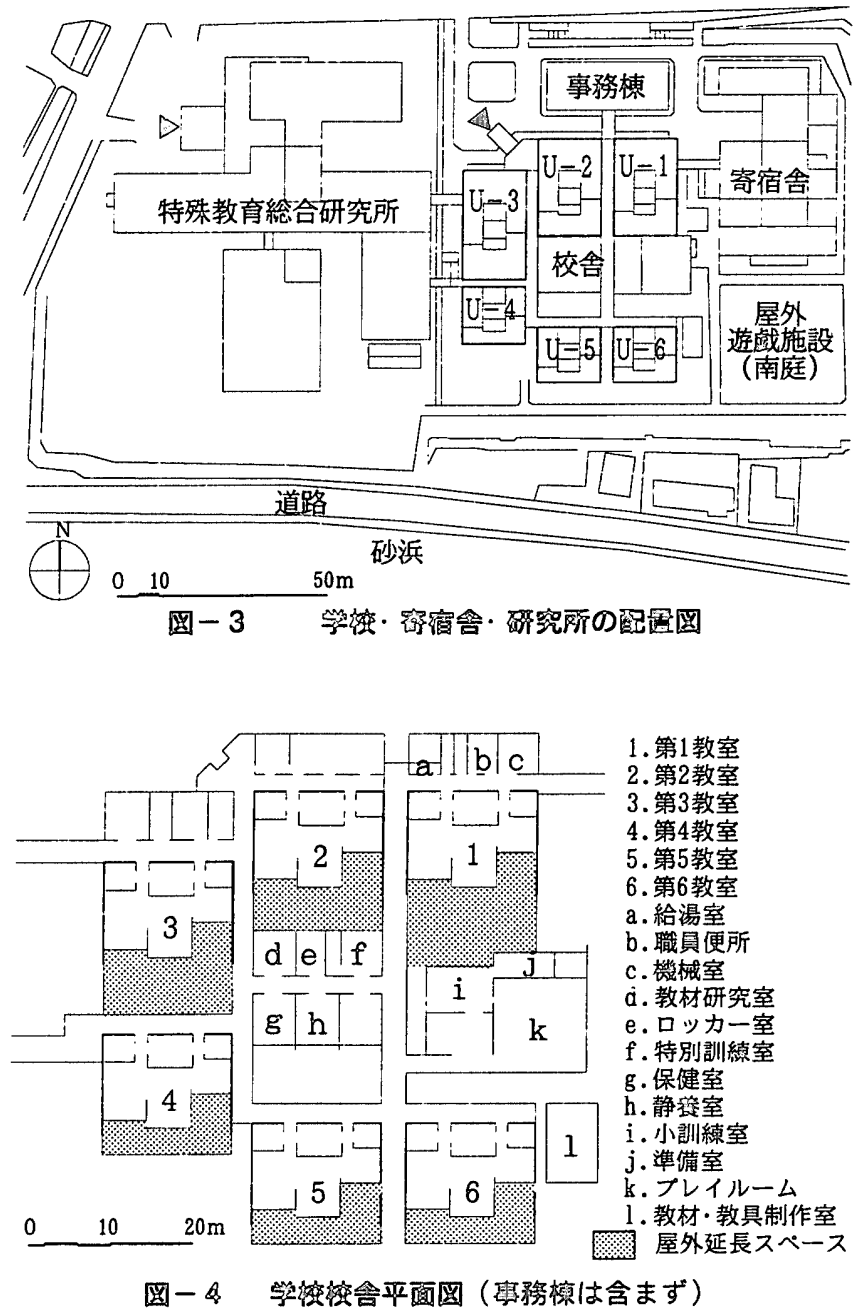


\section{1-2-1 設立時における教室ユニットの計画条件}

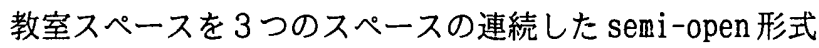
とした。3つのスペースは、壁面の長さ、天井高に変化をつ け、それぞれ特色をもたせ、使い方に融通性を持たせた。具 体的な計画条件として次の点に留意した。

(1) 個別学習と $3 \sim 4$ 人の集団学習のスペースを確保する。 個別学習の場は「特定の幼児・児童の場」であり、基本計画の 段階においては教育の対象となる幼児・児童の障害の程度は 詳細には予測できなかった。このため、スペースは固定的な 壁ではなく教材・教具によってつくり出す。集団学習の場は、 教室内の幼児・児童がすべて集まれる広さをもつこと。学習 活動に必要な教材・教具を手のとどく範囲に配列できる広さ をもつこと。

(2) 静かなスペースと動きのあるスペースを分けること。落 着きのある䨌囲気と活動的な行動を行うことができるスペー スを設け、両者は連続的に一つのスペースをつくること。両 者の相違を具体化するために活動的なスペースの天井高は高 くとること。

(3) 生活訓練と学習が内容的に分離できないため、教室内に 食事スペースをとること。食事スペースの近くに流しを設け、 手洗い、洗面の便利さを図ること。

(4) 排泄スペースも学習の内容に含まれる。教室の中に設け 利用の便利さを図る。スペースを十分に確保すること。

(5) 内部スペースに連続した外部スペースを設けること。幼 児・児童の学習活動が必要に応じて、そのまま屋外に連続し て行われること。

(6) 教諭、研修生、研究員が指導に当るために必要なスペー スをあらかじめ想定しておくこと。教室の中に教員室（研究 室) を設け、教育実践の計画と記録を直接記録できるスペー スを確保すること。

(7) 教材・教具を収納するスペースを十分にとること。

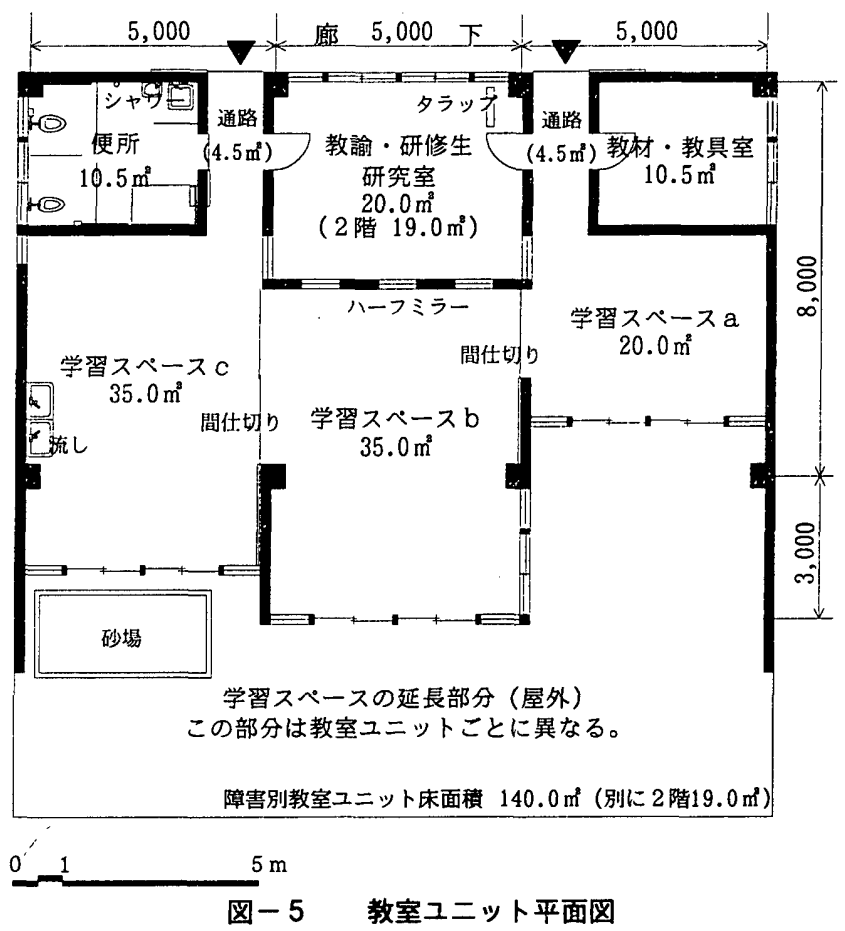

\section{$1-2-2$ 設立時における \\ 教室ユニットの床面積構成}

図ー5に本校の教室ユニットを示した。研究所の研究組織 に対応して、学校全体で主たる障害別に 6 ユニット配置され ている(図ー4参照)。各ユニットは3つに分割され、それぞ れ引戸(ハンガー式)によって開閉が自由である。本稿では右

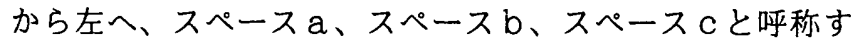
る。教室ユニットの床面積の合計は $140.0 \mathrm{~m}$ 、別に研究室の 上部に観察室（主として外部からの見学者のために設けられ た）として $19.0 \mathrm{~m}$ のスペースが設けられているが、本稿の研 究目的に見学者は含まないこと、現在は日常的に利用しない 書類などの収納庫となっているため教室ユニットの床面積に は算入しない。各部分の床面積は四に示したように、スペー

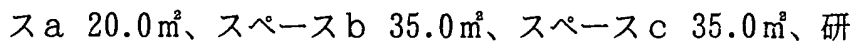
究室 $20.0 \mathrm{~m}^{2}$ 、便所 $10.5 \mathrm{~m}^{2}$ 、教具 - 教材収納室 $10.5 \mathrm{~m}^{2}$ 、通路

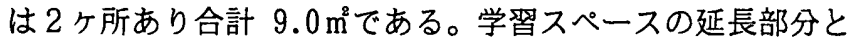
しての屋外スペースは配置によって差異があるが、約 $70.0 \mathrm{~m}^{2}$ 〜 $100.0 \mathrm{~m}^{2}$ の範囲である。

\section{2 調查の内容と方法}

\section{2-1 調查内容}

第 1 〜第 6 教室ユニットにおける幼児・児童の学習形態を 観察調査することによって、計画条件がどのように満たされ ているかを検討する。調査内容は幼児・児童の教室ユニット 内における動きと教材・教具の配置を観察し記録した。教室 ユニットの外にあるプレイルーム、特別訓練室及び屋外訓練 スペースにおける観察は含まれない。

\section{2-2 調查方法}

\section{2-2-1 観察調査}

各教室ユニットこととに観察記録員 . 2 名を配置し、始業時間 午前 10 時から終業時間午後 2 時 30 分までの幼児・児童の動き を平面図の上に記録した。調査日の選定は事前に予備調査を 行ない、調査当日は通常の指導が行われていることを確認し た上で決定した。調查日の天候は晴、屋外での指導を行うに は適していた。

第 1 教室 1995 年 1 月 24 日(火)曾/第 2 教室 1995 年 1 月 30 日(月)晴 第 3 教室 1995 年 1 月 26 日(木)晴/第 4 教室 1995 年 1 月 25 日(水)晴 第 5 教室 1995 年 1 月 27 日(金)晴/第 6 教室 1995 年 1 月 23 日(月)晴

観察記録は 4 時間 30 分の間休みなく行われた。この学校で は食事指導、排泄指導、及び他の教室(例、プレイルーム)へ の移動も単位時間内における学習とされている。本校の単位 時間は、時間割の上では概ね 30 分、業間に $5 \sim 10$ 分の休㮩時 間を設けている。しかし実際の学習は連続しており、観察の 上では区分が明瞭ではない。このため、教諭らには休䕀時間 はとれない。なお、幼稚部の始業は午前 10 時 30 分、終業は午 後 2 時である。

\section{2-2-2 担任教諭に対するヒヤリング調査}

観察調査の前後に各教室ユニットの担任教諭に対し、教室 ユニット全般にわたる使われ方についてヒヤリング調查を 行った。表一 2 はそれぞれの教諭が本校に在職している期間 を示したものであり、かなりの幅がある。19 年 9 ケ、17 年 
9 ケ月、15 年 9 ケ月、 12 年 4 ケ月の長い経験を持つ教諭が在職 している。在職期間の長い教諭からは建物の使われ方の経年 変化について意見を聞くことができた。

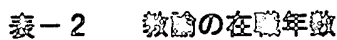

\begin{tabular}{|c|c|c|c|c|c|}
\hline 教室 & \multicolumn{3}{|c|}{ 教諭の本校在職年数 } & \multicolumn{2}{|c|}{ 平均年数 } \\
\hline 第1教室 & $\overline{2: 09}$ & $4: 09$ & $15: 09$ & $0: 09$ & $6: 00$ \\
\hline & $2: 09$ & $19: 09$ & $7: 09$ & $0: 09$ & $7: 09$ \\
\hline 第3教音 & $17: 09$ & $0: 09$ & $2: 09$ & $2: 09$ & $6: 00$ \\
\hline 第4教䓨 & $8: 09$ & $0: 09$ & $1: 09$ & $2: 09$ & $3: 06$ \\
\hline 第5教室 & $12: 04$ & $3: 09$ & $1: 09$ & $2: 09$ & $5: 01$ \\
\hline 第6教韹 & $1: 09$ & $1: 09$ & $2: 09$ & $0: 09$ & 1:0 \\
\hline
\end{tabular}

※数字はそれぞれの担任する敨諭の年数を（年：尺）を示す。

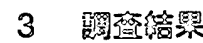

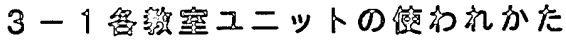

各教室ユニットの使われ方は、教材・教具の配置とそれぞ れの形状・寸法の㨙取、ユニット内の幼児・児童の動きを記 録することによってその実態を把握した。教材。教具の配置 驻幼児・児童の個別学習スペースを形成するためにコーナー をつくり出している場合、また集団学習のためにできるだけ 広い床面穓を確保するために教材・教具は隅部にまとめられ ている場合に大別されている。

幼児・児童の動きの記録は各教室ユニットの内部に限定し た。校舎内にある他の教室またはプレイルームに移動した場 合には調荟記録では単に「校舎内」とした。屋外について も、当日は晴天であり日光浴。運動のために屋外の複数の訓 緦スペースに出た幼児・児童も多いがこれらの移動もすべて 「屋外」と記録した。各教室ユニットの使われ方の結果につ いて、(1)教材・教具の配置図、幼児・児童と教諭の位置図、 (2幼児・児童の移動を場所と時刻別に示した表及び対象幼 児・児童の特性の概略、(3)ユニット内の各スペースの使われ 方について図ー6〜図-17及び表ー3〜表ー8で表した。

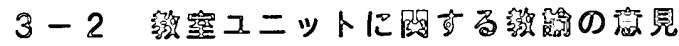

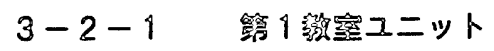

ユニット内の全児童が臥位の姿勢であることから、教諭の 意見として児童の学習・生活の行動範囲を拡大するために移 動のための装置が欲しいという要望が強い。例えば天井走行 式リフトがあればユニット内での狭い生活空間から児童が開 放され校内の主要な学習の場( 特別訓縝室、プレイルームな ど）への移動が容易となる。卧位のため児童の視線は床面に 近く、学習の効累も著しく制限を受けている。移動式の畳敷 きの設備を設ければ、児童の視線は高くなり、教諭も共に横 になることが可能となり指導上便利であることを教諭は指摘 している。また各スペースの採光・照度についても光の変化 を可能とする装置を教諭は希望している。便所に对する改善 の意見も多く。具体的には暖房が欲しいこと、便座の位置は 児童 1 人 1 人よって異なること、おむつ交換用のベッドは必 ず設けること、など教諭の設備改善の要望は強い。

\section{$3-2-2$ 解 2 弱室ユニット}

このユニットは使われ方として最も特色があるため教諭の 意見も多い。第一に情緒障害児のために落着いた個別スペー スが欲しい。そのスペースは狭く囲まれたものであり、教室 ユニットとしても建物の構成の上で考えて欲しい。これとは 逆に、この教室ユニットには多動性の児童がいるため、児童

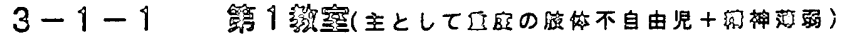
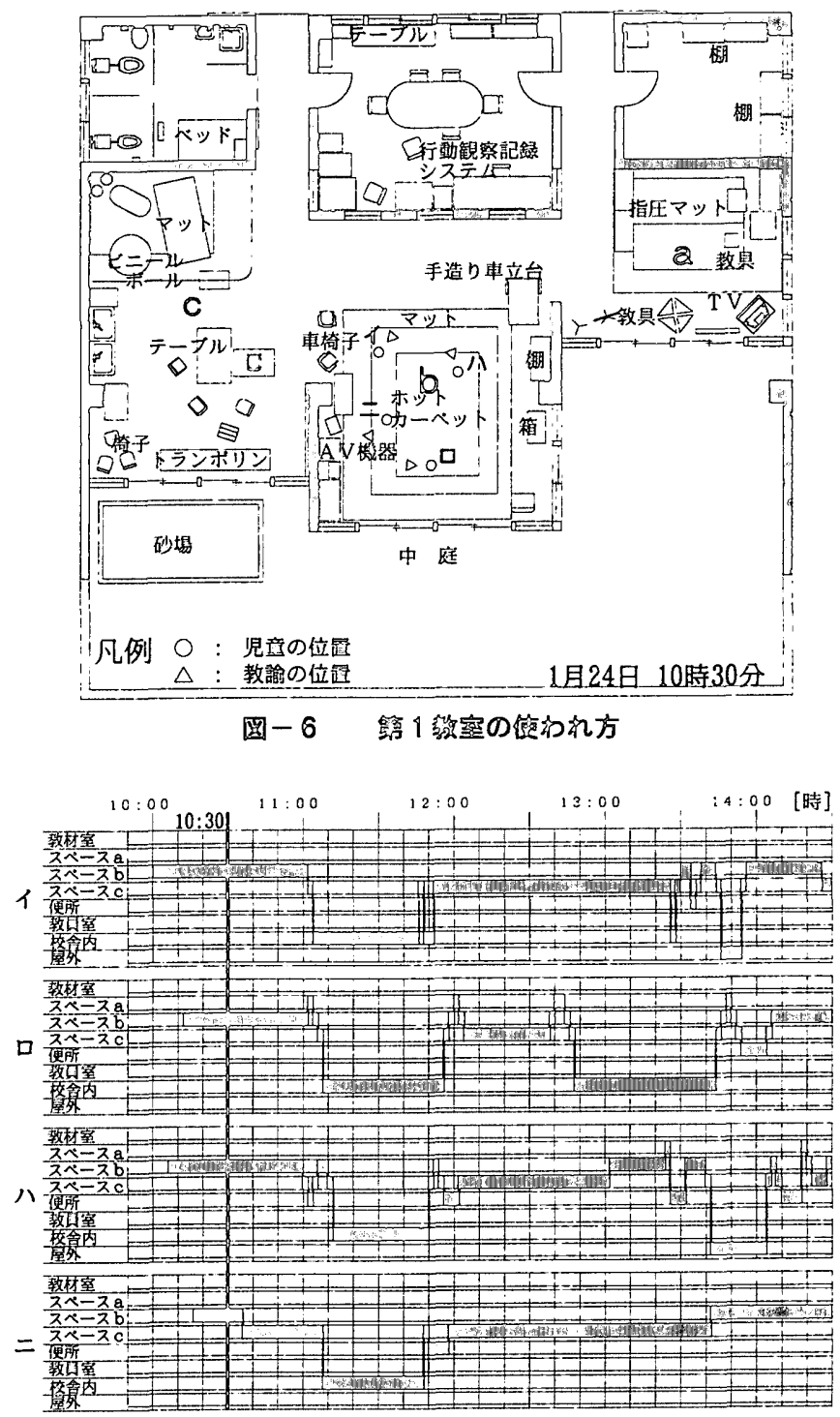

$1:$ 小 $-3 /$ 女/卧位。自力で應位图難。食孚、排泄、全面介助。 散歩を好む

口:小ー3/男/臥位（自力で姿势変換できない）。喘鳴あり。食赦は経管 に上る栄究摄取。大型遊具好む。

八: 小ー1/男/卧位。おむつ使用。便所を使うこともある。ボディリニりの

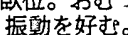

ニ: 小ー1/女/䐘卧位で少しずつ前進可能。食享、排泄、全面介助。光と 音に興嘜ある。

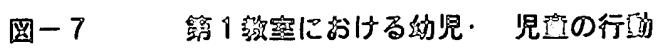

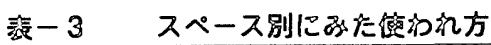

\begin{tabular}{|c|c|}
\hline スペース & 炧方㣗方 \\
\hline 教材室 & 出入りする児童はいない。 \\
\hline スペース & 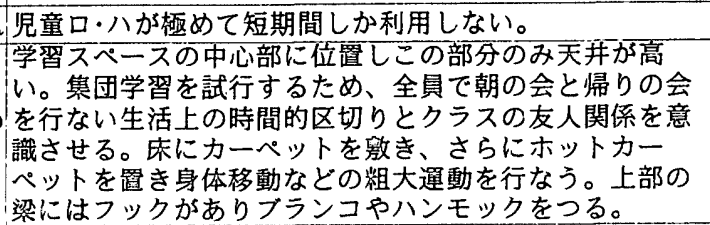 \\
\hline & $\begin{array}{l}\text { 図の上半分は個別学習の場となり下半分は集団学習·生活 } \\
\text { 繒の場として利用されている。 }\end{array}$ \\
\hline 便所 & 刓童口が 4 回、他の 3 名はそれぞれ 1 回づつ利用。 \\
\hline 研究室 & 児童ロ・ハ・二が短期間出入りしている。 \\
\hline 校舎内 & 特別訓練室への移動である。 \\
\hline 屋外 & $\begin{array}{l}\text { 調査日の天候が晴れであり教室ユニットを出て教諭に全 } \\
\text { 面介助されなから校地内を散歩している。 }\end{array}$ \\
\hline
\end{tabular}




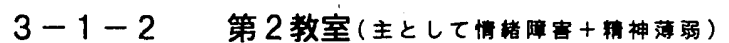
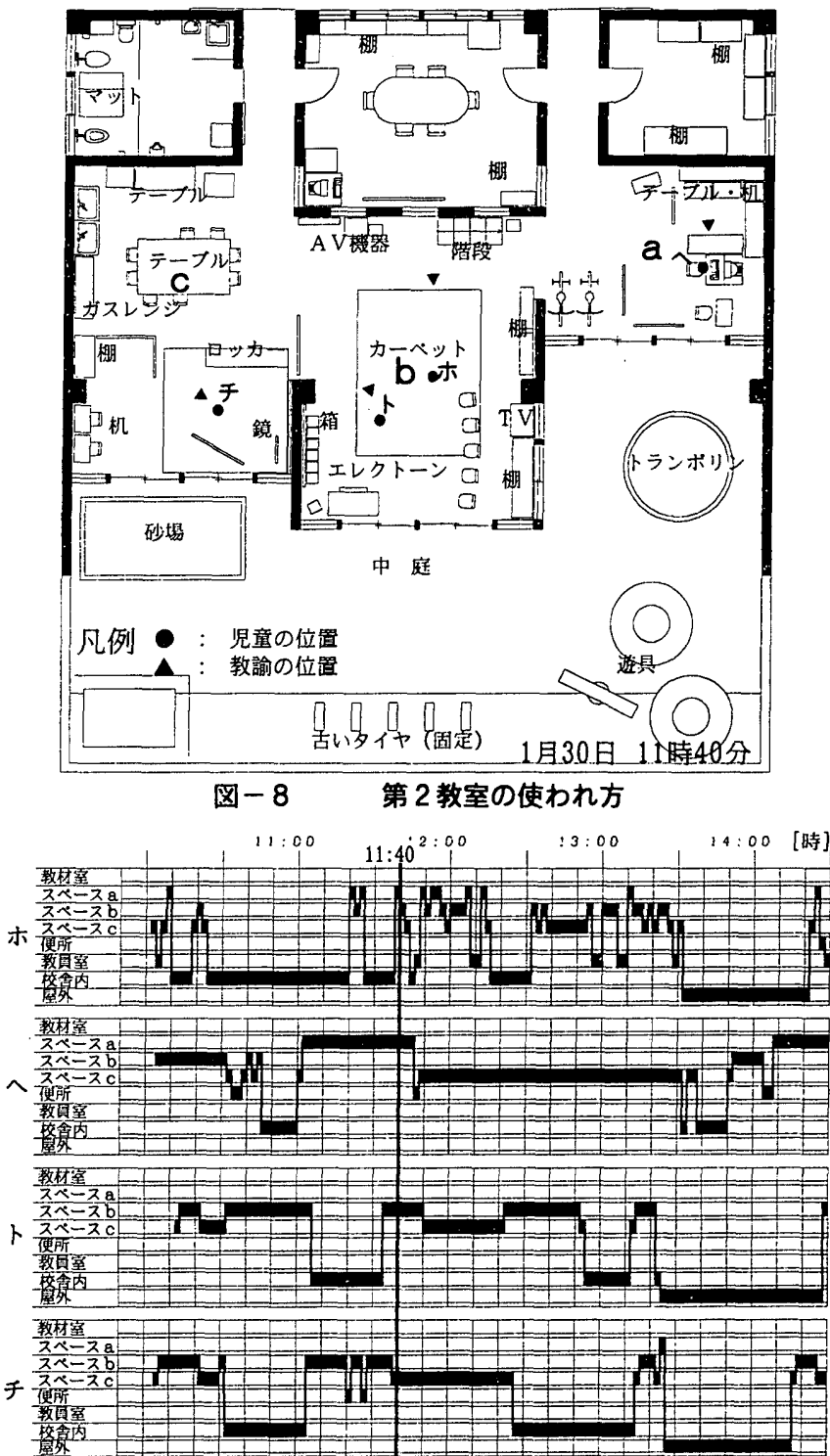

ホ: 小ー4/女/自立歩行可能。日常生活は自立している。

へ: 小ー3／男/日常生活は自立しているが環境の変化には対応しにくい。 パソコうに興味ある。ふららんこを好む。

卜 : 小ー5/男/介助による立位走行可能。日常生活は半自立。 光や光の反射に興味ある。ビデオ、絵カードを見る。

チ : 小-1/男/日常生活はほほ自立しているが、教諭への依存傾向か ある。萧り物、大型ボー北どを好む。

图ー9 第2 教室における幼児・児童の行動 表ー4 スペース別にみた使われ方

\begin{tabular}{l|l}
\hline スペース & 使われ方 \\
\hline
\end{tabular}

教材室 出入りする児童はいない。

児童への比較的長時間にわたる利用が目立つ。児童ホ

スペース $\mathrm{a}$ 崖、基本的生活習慣をほほ自立しており、歩く走るなど の身体機能はさほど問題がないためスペース a, b, c，を頻繁に移動している。

情緒障害を伴う児童が多いために他の教室のように全圆

スペースbで朝の会がこの調查日では開かれてないことが注目され る。しかし朝の会は学校生活の区切りと、めりはりをつ けるために重視されている。

スペース児童ホを除いた他の3人は、長期的に食事の場として利用 スヘースししている。

便所児童へが3回、児童チが2回、児童ホが1回づつ利用。 研究室坚童ホが頻繁に出入りしている。

校舎内 教室ユニットから外に散歩に出る児童が多い。

屋外 4人の児童すべてが屋外遊びのために教室ユニットから外 に出ている。

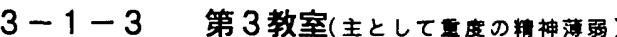
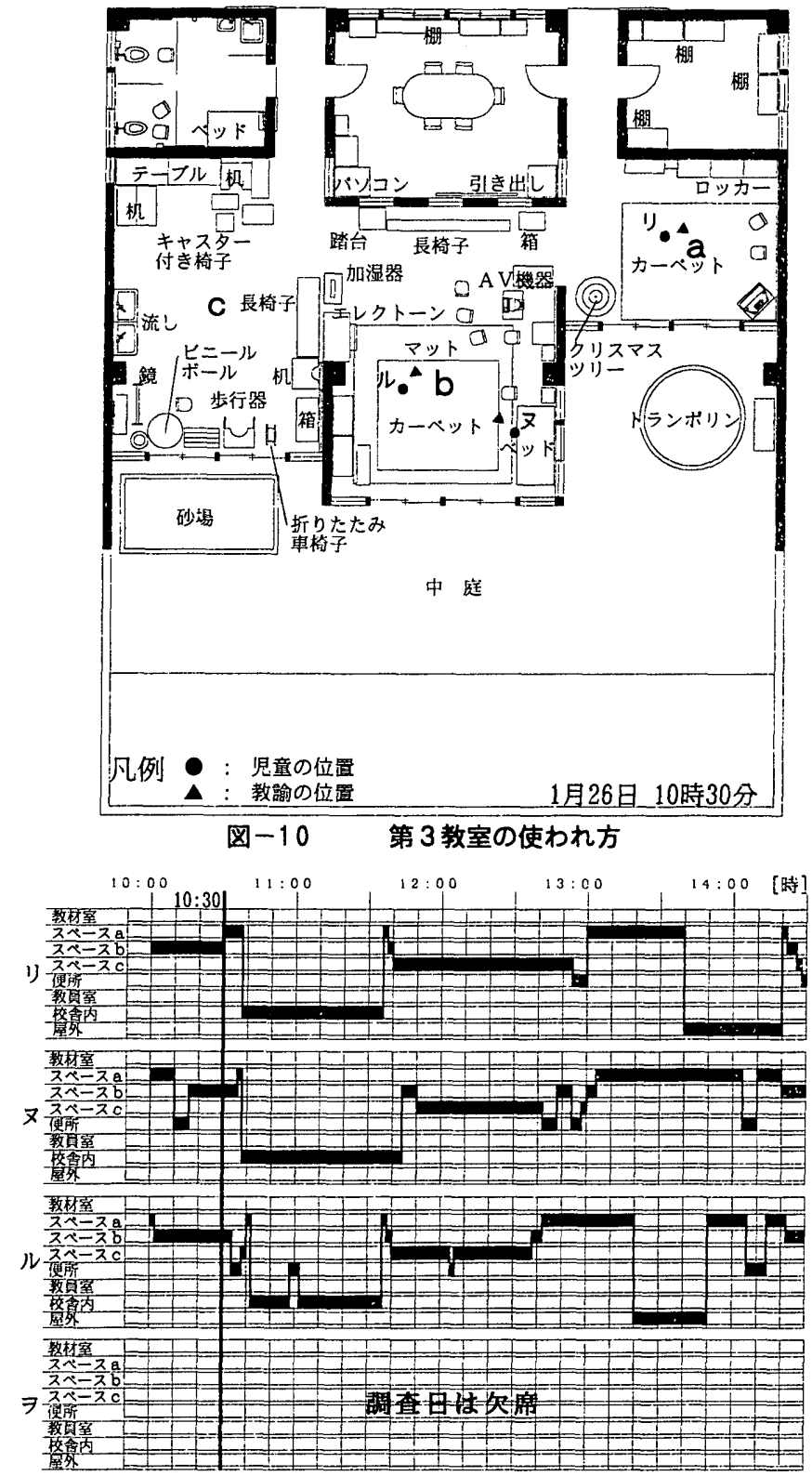

リ: 小ー6/男/介助による立位走行可能。排尿を知らせることができる。 又:小ー4/女/座位を舆くとることができる。食事、排泄、全面介助。

ル:小-2/女/不安定な立位、走行加可能。食事、排泄、全面介助。 ᄏ: 小-5/女/(調査日欠席)

\section{图-11第 3 教室における幼児・児童の行動}

\begin{tabular}{|c|c|}
\hline 表 -5 & スペース別にみた使われ方 \\
\hline スペース & 使われ方 \\
\hline 教材室 & 児童の出入りはない。 \\
\hline スペース $a$ & $\begin{array}{l}\text { テレビを見たり、休息の場として使われ、3名全員が利 } \\
\text { 用している。更衣の場ともる。 }\end{array}$ \\
\hline スペースb & $\begin{array}{l}\text { 朝の会に全員が集まっている。セラピーマットとホット } \\
\text { カーペットか數かれている。 }\end{array}$ \\
\hline -スc & $\begin{array}{l}\text { 全員の食事の場である。大型遊具を使う機能訓練とな } \\
\text { る。 }\end{array}$ \\
\hline 便所 & 児童ヌ、ルは 4 回、児童リは 2 回利用している。 \\
\hline 研究室 & 児童の出入りはない。 \\
\hline 校舎内 & 午前中は全員プレイルームに移動している。 \\
\hline 屋外 & 児童り、ルは午後散歩。 \\
\hline
\end{tabular}




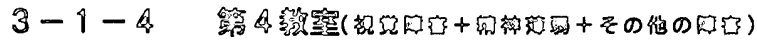
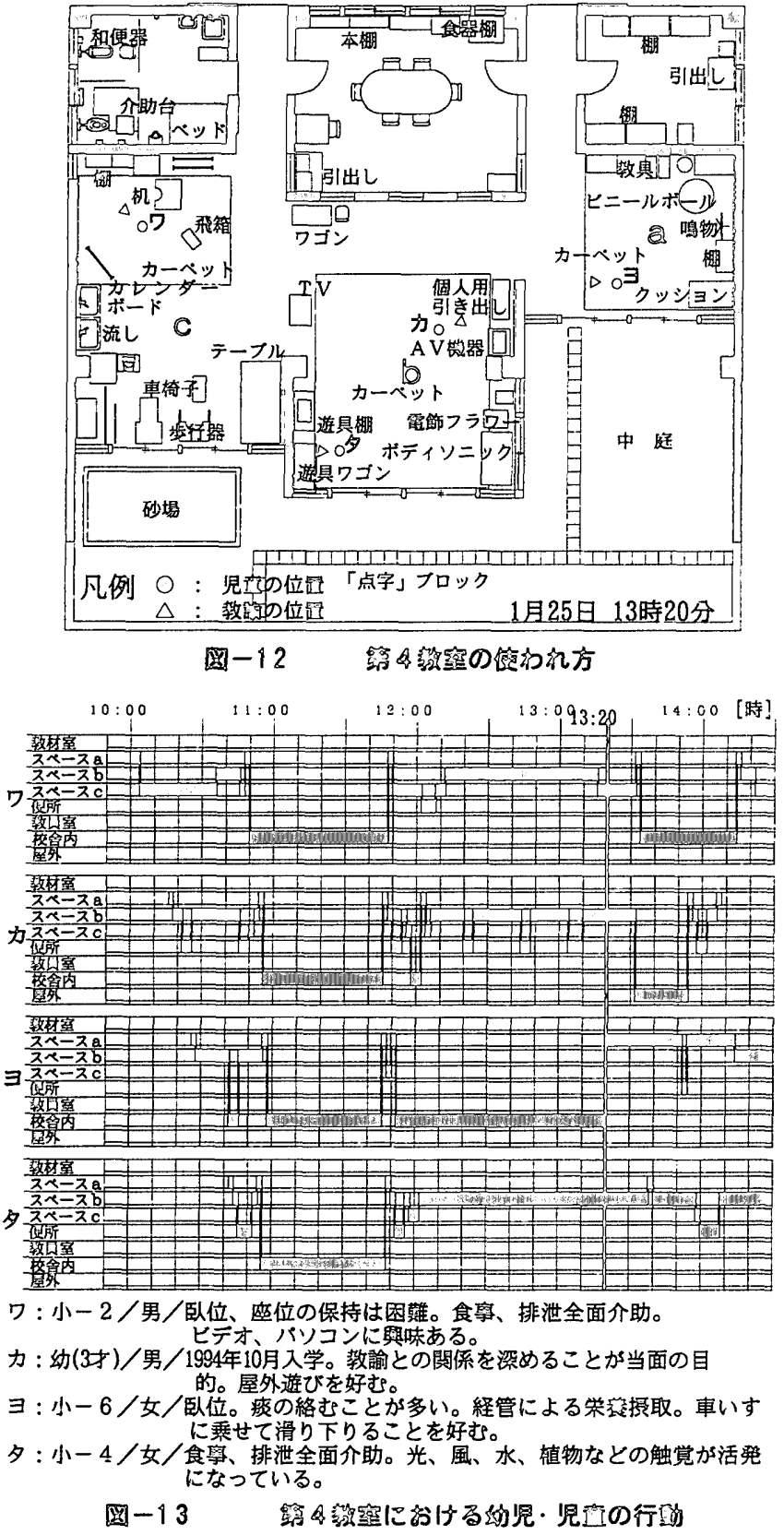

\begin{tabular}{|c|c|}
\hline 演一 6 & 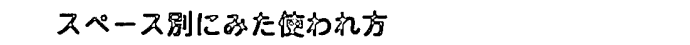 \\
\hline 2ペース & 距引沉方 \\
\hline 教材室 & 幼児・児衁の出入りはない。 \\
\hline & $\begin{array}{l}\text { 幼児タの利用が多いか、他の 3名も断片的に利用してい } \\
\text { る。 }\end{array}$ \\
\hline & 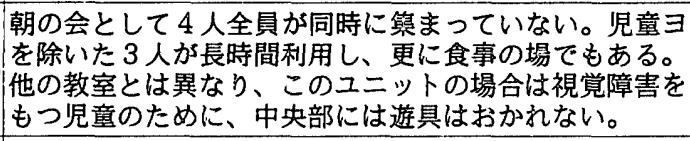 \\
\hline ᄌ & $\begin{array}{l}\text { 图の上部は児童ワの個別学習の場となっている。他の児 } \\
\text { 亶の利用は少ない。 }\end{array}$ \\
\hline 便所 & 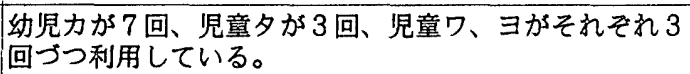 \\
\hline 研究室 & 幼児、児童の出入りはない。 \\
\hline 校舎内 & 児童ヨが長時間にわたって保健室に移動している。 \\
\hline 屋外 & 幼児カのみ散歩に出ている。 \\
\hline
\end{tabular}

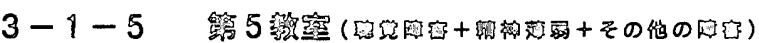

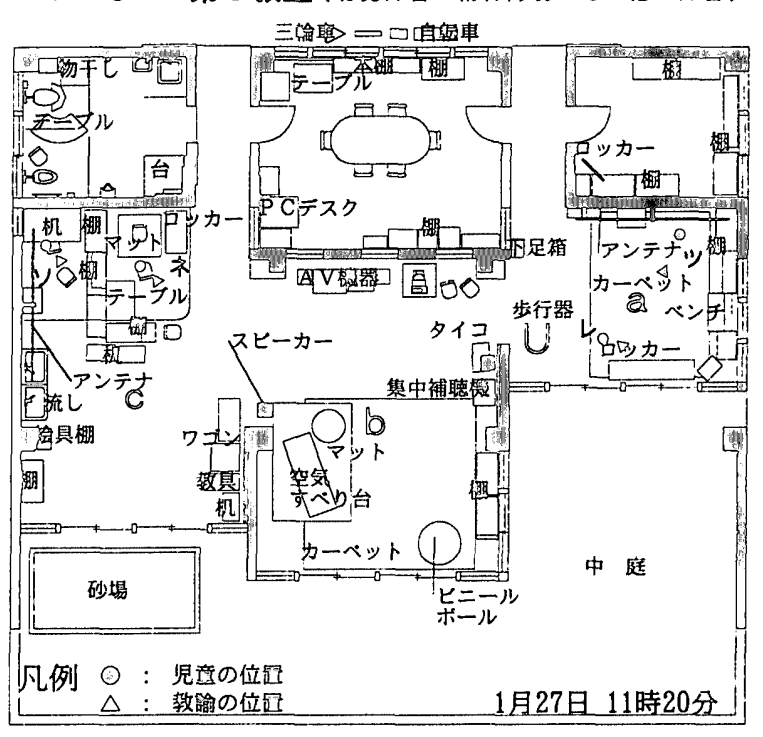

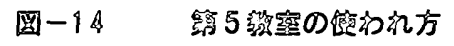

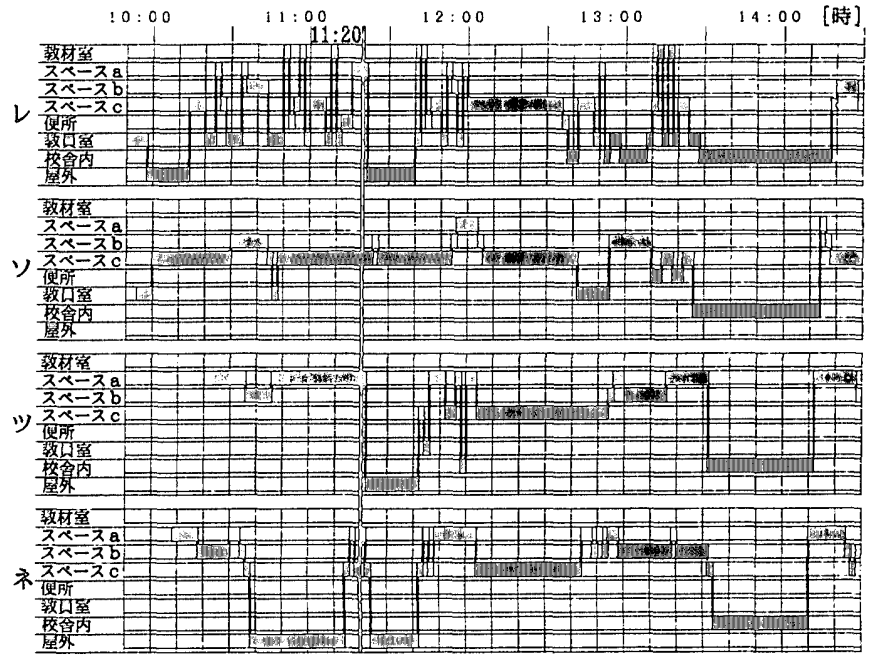

レ : 小ー6/男/歩行は不安定であるが、日常生活はほぼ自立している。

写嬪力ートによる学習。太散の音に與哧あり。

ソ: 小ー6/男/食䙷に介助加必要。排泄性繁多い。高いところを歩くこと を好む。

ッ: 小ー4/女/安定した歩行が可能である。日常生活はほほ自立している。 ふらんこの立ちのりを好む。

ネ：幼得り女/座位は安定している。食搴は半介助。排泄は紙おむつを利用。

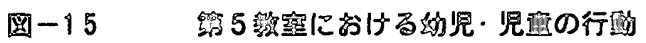

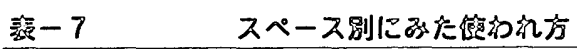

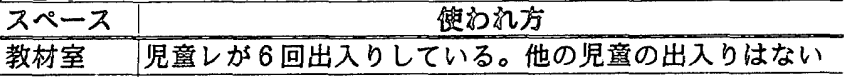
児童レの利用回敏は多いが出入りだけである。呪童ツと

スペースa幼児ネは個別学習の拠点としている。更衣、おむつ交換 の場である。

幼児、児童の 4 人全員が利用している。通常、朝の会、

スペース b 帰りの会の場となるが、調荟日には全貣が焦まってはい である。

図の上半分は児音レ、児童ソの個別学習の場である。下

スペースc|半分は全員の食亨の場となっており、上下で明確な使い 方の区分がなされている。 便所 韭童レは 4 回、児童ソは 2 回利用している。児鵙ツと幼

研究室 児意レか頻繁に出入りしている。児童ソの出入りもある

校舎内 午後、全員がプレイルームに移動している。

屋外睍童りを除いて3人が散歩にでかけている。 
3-1-6 第6 教室(主として面度の肢体不自由十神薄弱)

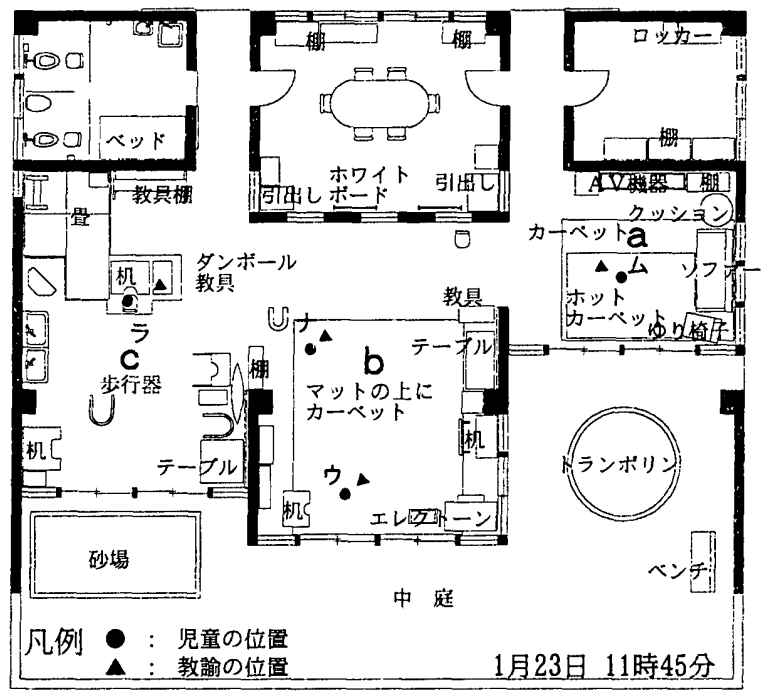

图-16 第6 教室の使われ方

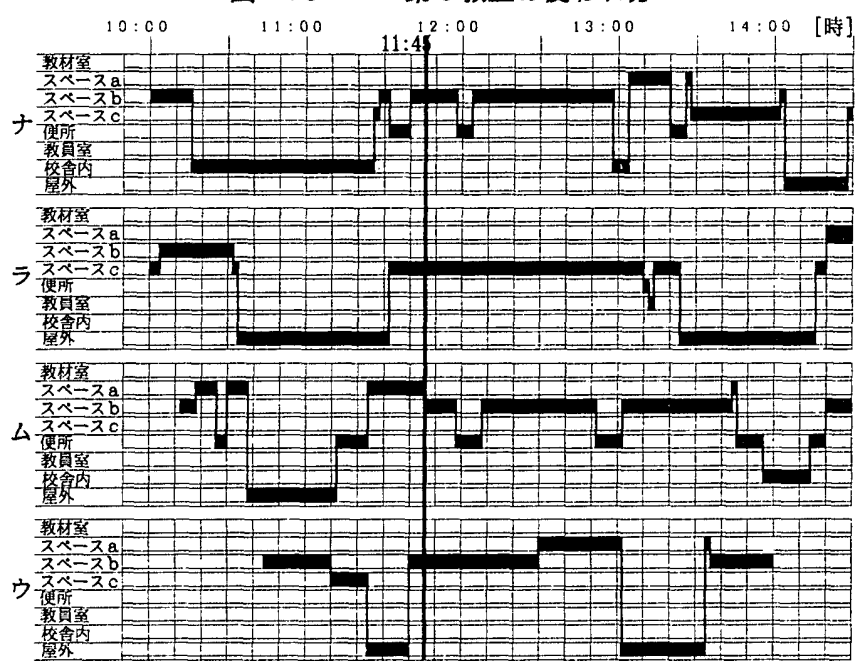

ナ: 小ー1/女/卧位、座位は自力では困難であるか、トランボリン、ふら んこなと全身を動かす遊ひを好む。 ラ: 小ー4/女/卧位、坐位可能。教諭将本人の視線によって意志を確認て

ム : 小ー 3 /女/座位を保つ事ができる。歩行器による歩行も可能である。 ウ: 幼䦻V女/卧位、座位は自力では困難。移動は寝返って目的地に向か

図-17

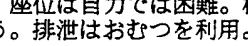

第 6 教室における幼児・児童の行動

\begin{tabular}{|c|c|}
\hline 表-8 & スペース別にみた使われ方 \\
\hline スペース & 使われ方 \\
\hline 教材室 & 幼児・児童の出入りはない。 \\
\hline ス・ & 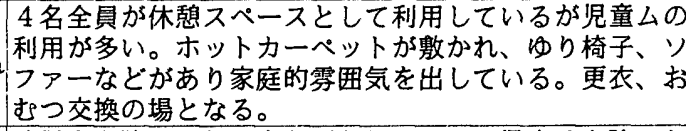 \\
\hline - $2 b$ & $\begin{array}{l}\text { 幼児ウを除いて朝の会が開かれている。児童ラを除いた } \\
3 \text { 名の機能訓練、日常生活訓練の場であり、食事の場と } \\
\text { なっている。活動後は横になって休む場ともなる。 }\end{array}$ \\
\hline スヘ & 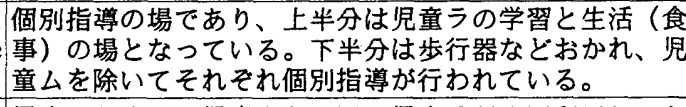 \\
\hline 便所 & $\begin{array}{l}\text { 児童ムが } 6 \text { 回、児童ナが } 3 \text { 回、児童ラが } 1 \text { 回利用してお } \\
\text { り、利用頻度は高い。 }\end{array}$ \\
\hline 研究室 & 児童ラが 1 回出入りしている。 \\
\hline 校舎内 & 児童ナ、児童ムがユニットから移動している。 \\
\hline 屋外 & $\begin{array}{l}\text { 幼児ウと児童ムは庭のトランオポリンを利用、その他の児 } \\
\text { 童は屋外散歩に出かている。 }\end{array}$ \\
\hline
\end{tabular}

の活動エネルギーを発散させる場も欲しい。例えばトラン ポリンを常時ユニットの中で利用したいという教諭の意見 がある。（現在では室内スペースが狭いので屋外の庭に置い てあるが、雨天時には利用できない）。さらに教諭の意見と して教室ユニットの中に調理スペース、図エスペースなど 水を使い床が污れてもよいスペースを組み込むことが要望 されている。さらに通常の家庭生活に対応できる生活訓練 の設備も欲しい。開校時、この教室ユニットのスペースc に直径 $3.5 \mathrm{~m}$ 、深さ $30 \mathrm{~cm}$ の円形の温水プールを設けてあった が周辺の床が濡れて滑り易く危険であるという理由で廃止 されたがプールは有効であった。中庭に屋根のあるプレイ スペースがあれば幼児・児童の活動は屋外と屋内を連続し て一段と活発化されるため、早急に整備して欲しいという 教諭の意見も多い。砂場は污れの問題があり工夫( 例えば机 上の高さに砂箱として設ける) が必要であると教諭が指摘し ている。

\section{3-2-3 第3教室ユニット}

立位歩行が困難な児童が多いこのユニットに対する教諭の 意見は児童の転倒による事故防止である。コンクリートの 上にPタイルを貼った仕上げは固く、木造仕上げを含めた 柔らかい床面を教諭は強く希望している。トランポリンの 利用も指導上効果があり、これを常時、置くスペースも教 諭から要望されている。現状では、ユニットの庭に設置し ている。スペース bの天空も、天候の良い時は開ける設備 としてほしいという意見がある。重度の児童は一つのこと に必要以上にこだわるケースがあるが、この学校で壁に貼 られている吸音ボードの穴も児童によっては非常にこだわ りをもっている。壁の仕上げに注意してほしいという教諭 の意見がある。空調を集中式ではなくスペース $a 、 b 、 c$ に対応できる個別式のものが教諭によって要望されてい る。

\section{3-2-4 第4 教室ユニット}

教諭の意見によれば視覚障害を持つ幼児・児童の行動は 各自が決めた起点から始まる。記憶されたスペースの形を 理解するには判り易い空間が必要であり、教材・教具を きっちりと定位置に置きたい。したがってスペースの中央 部にものを置かなくとも済むように整理できるスペースを 必要とする。さらに教諭の意見として色彩計画も重要であ り、他の教室ユニットとは区別された色彩にして欲しい。 床マットの位置も色彩を変えることによって明暸に示した い。指導する立場からみて暗い部屋( 暗闇の中で光を見る) が欲しい。その装置( 光調節、間接採光など) を教室ユニッ トの中に設けたい。水との接触を好むため水の流れる装置 が欲しいという教諭の意見がある。

\section{3-2-5 第 5 教室ユニット}

動きが活発な幼児・児童が多く室外に出ることが多いため 建物のつくり方、特に室内と室外とは関連することに注意 して欲しい。中庭ではテラス設けて雨天のために庇をつけ て欲しいという教諭の意見がある。室内は見通しをよくし 児童の位置を確認しやすいようになっていると指導の立場 
からみて都合がよい。食事のために現在のスペース c ではな く食事室を設けて欲しい。集団補聴設備(床アンテナループ) は校舎全体に設備してほしい。

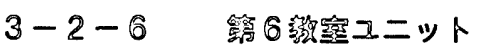

臥位と座位の多いこのユニットに対する教諭の希望は床面 に柔軟性がほしいこと、介護する教諭の負担を㪕減できる装 置がほしいこと、など第 1 教室ユニットとの穎似点が多い。 小学部も高学年になると行動䈯囲が拡がるが、庭に面してひ さしのあるべランダがあれば有効であり屋内の延長スペース としての中庭の利用も可能となると指摘する教諭の意見があ る。建物、設備ともに大人の寸法で設計されており、幼児の 寸法に適していない。流し台、便所は利用しにくい。また教 育幾器を十分に活用するために多くの電源が必要であり、コ ンセント数が不足しているなど教諭からの意見が多い。

Q 就と的

(1)本校ではユニットの中に中庭を設けたため学校全体がク ラスター状の配置となり各ユニットのゾーンが明確化し ている。障害ことに落着いた空間をつくることには利点 が多いが、反面、障害別クラスの相互交流を実践する場合 は極めて不便である。艾舎中の動線も単純ではなく、見学 者の中には自分の現在位置を見失う場合もある。廊下の 幅員を拡大することを含めて更なる工夫が必要である。

(2)調至結果が示したように、自力で移動できる幼児・児童の いるユニットと全員自力で移動できないユニットではユ ニットの形態が同一である必要はない。活動的なより広 いスペースが必要なユニットと、もっと狭いスペースが 必要なユニットもある。屋外空間と屋内空間の相互貫入 も多様性が必要であり、現在の画一的平面には改良すべ き点が多い。室内の形態についても同様であり、6 種すべ てのユニットが同一のパターンである必要はなく、形状 についても多様性が必要である。

(3)各ユニットは、スペースの性格についても、もっと性格 をはっきりさせることが迫られている。静かな落着いた スペース、活動的な天井の高いスペース、少し暗いスペー ス、水や流しの設備、污れてもすぐ洗浄できるスペース が必要である。

(4)床面稳の面からみて最も問題を抱えているのは量の多い 教材。教具を置くスペースである。これは収納を目的とす る教材室を広くすればよいという問題ではなく、学習ス ペースから手のとどく匴囲に常時置いておく必要があり 教枋。教具が通常の学習スペースに比較してさらに広いス ペースを必要としている。

楊とが

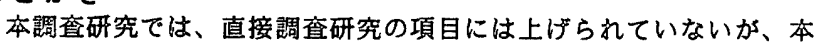
稳の目的に瑯して基本設計者としての立場から現在の久里浜落設学校 の現状をみると、次の 2 点が指摘できる。

床仕上げは開校当時の建設盎情によってコンクリート床の上に P夕 イルを貼ったものであり障害児の立場からみるときわめて危険であ る。最近の小。中学交と同様に不造校舎の再評価とともに床も本造と する必要があり、本調㸖結累の中でも常に指摘した点である。柱や壁 の掼部に対する配虑も考えておか的ばならない。床の上で生活する幼
児・児童の立場からの考察は心理的・視覚的にも必要である。本校も この種の配㴔が不足していた。

設備機器は時代とともに急速に発展するため、固定的な建阵躯体と

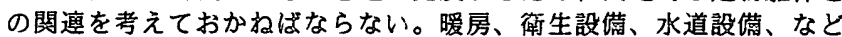
は躯体と別に必要に応して交换が可能な設計であるが本笠ではこの対 応が不十分であった。本校では研究室が児童の行動観察室になってお り情報処理機能が組み込まれている。学習スペースでもコンピュー

夕、T Vなとの電源の必要なものが年々急這に增加しており、本校の ように在来の設備システムでは将来の変化に対応できないことは明確 である。

\section{路}

本研究に際して長年にわたり観察調䏣の埸を与えてくださった国立

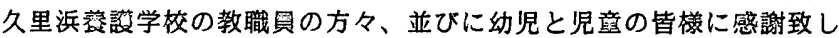
ます。等者は基本計画から本校と関わりを持ち以後 27 年間、本校の 成長を見てまいりましたが、この学校は開校以来、年とともに成長し ています。通常、建物は経年とともに老轫化しますが、本艾では適切 な補修もありますが先生方の教育に対する熱意が教育の場を年々圕か な成長をさせるという䝿重な例外的な学校です。研究調査に参加した 著者の研究室の諸君にも感謝致します。特に今回の調㚗に参加した、 岡埼宙展君、原安芸子君をはしめ、資枃整理を担当した佐藤直澍君、 岡田真人君に感謝します。

泣

1) 複数の教室を篹め平面上一つのまとまりをつくる。通常、便所 ・ 手洗、更衣スペース、ワークスペースなどを包含する。

2 ) 明治以来、障害別に発達してきた日本の特殊教育の研究を総合的 にかつ実践的に研究するために神奈川県横須賀市に1971 年に開所 した。(著者はこの基本計画も担当した)

3）後上鐵夫 国立久里浜言設学校 学校二十年誌 1992 年

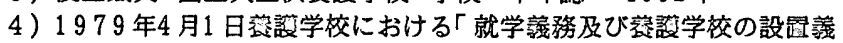
務」施行

5 ) 本校では乳幼児発達梌㿽法としてこの方法を採用している。各年 度の教育年報に収録されている。

6) 研究所の設四目的の一つに研修があり、1996 年現在、長期研修1 年間 $(50$ 人)、短期研修 3 ヶ月 $(300$ 人)がある。

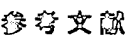

1) 原安芸子, 関澤勝一, 柳田武: 国立久里浜裳設学校におけるサ二 タリースペースのあり方に関する研究, 日本建築学会大会学術請 演梗概舅， E-2 建築計画 II，pp. $73 \sim 74 ， 1996$

2 ) 原安芸子, 関澤勝一, 岡的宙展: 国立久里浜蓄設学校における教 室の使われ方に関する一考察, 日本通築学会大会学術講演梗既集， E-2 建築計画II, pp.305 306, 1995

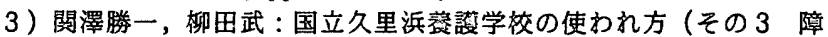
害別教室ユニットの使われ方), 日本建築学会大会学術䆛演梗維 焦, E 建筑計画, pp.1183 1184, 1978

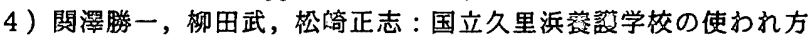

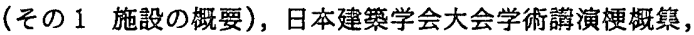
計画系, pp.1095 1096, 1977

5) 関澤勝一，柳田武，松埼正志 : 国立久里浜落設学校の使われ方 (その 2 障害別教室ユニット), 日本建築学会大会学術噈演梗概 翼, 計画系, pp.1097 1098，1977

6 ）研究所二十年誌，国立特然教育総合研究所，1992.10

7 ) 学校二十年誌, 国立久里浜䕊榙学校, 1992.10

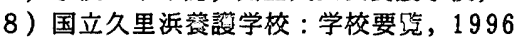

9 ）国立久里浜落證学校教育第 1 年報～第 22 年報, $1972 \sim 1994$

10）蕂原正人編，久里浜の教育同人会著: 雷度・重被障害児の教育, 久里浜桼設学校教育実践報告, 光生館, 1982.3

（1996年11月10日原稿受理，1997年 8 月20日採用決定） 